БАЛОБАНОВ О. О., кандидат юридичних наук, доцент, професор кафедри морського права (Навчально-науковий морський гуманітарний інститут Одеського наиіонального морського університету)

БУРДЕЙНИЙ Є. П., магістр

(Навчально-науковий морський гуманітарний інститут Одеського національного морського університету)

УДК 347.79:342.9(477)

DOI https://doi.org/10.32842/2078-3736-2019-6-2-1

\title{
АДМІНІСТРАТИВНА ВІДПОВІДАЛЬНІСТЬ ЯК ЗАСІБ ЗАБЕЗПЕЧЕННЯ БОРОТЬБИ З ПРАВОПОРУШЕННЯМИ НА МОРСЬКОМУ ТРАНСПОРТІ: ПОНЯТТЯ Й ОСОБЛИВОСТІ
}

У статтіна основі аналізу наукових поглядів розглянуто поняття й особливості адміністративної відповідальності як засобу боротьби з правопорушеннями на морському транспорті. Досліджено поняття адміністративної відповідальності, на підставі чого надається авторське визначення поняття адміністративної відповідальності за правопорушення на морському транспорті як різновиду правової відповідальності, специфічну форму негативного реагування з боку держави в особі їі компетентних органів на вчинення правопорушень на морському транспорті, згідно з якою особи, котрі скоїли ці правопорушення, повинні понести адміністративні стягнення у встановлених законом формах і порядку.

Проаналізовано, що адміністративну відповідальність за правопорушення на морському транспорті встановлено главою 10 Кодексу України про адміністративні правопорушення «Адміністративні правопорушення на транспорті, в галузі шляхового господарства і зв'язку». Поверховий аналіз складів цих правопорушень дає можливість стверджувати про відсутність чіткої їх системи. Для усунення цієї прогалини пропонується систематизувати правопорушення на морському транспорті на такі групи: правопорушення, що посягають на безпеку перевезення пасажирів і вантажів морським транспортом; правопорушення, які посягають на нормальну діяльність морського транспорту та його інфраструктуру; порушення правил поведінки пасажирів морських суден.

На підставі аналізу чинного законодавства та думок науковців зроблено висновки, що сьогодні проблемним $є$ питання щодо ефективності санкцій за вчинення правопорушень на морському транспорті. Так, здебільшого за їх вчинення застосовуються незначні суми штрафів - від одного до десяти неоподаткованих мінімумів доходів громадян, що, по-перше, не співвідноситься зі ступенем суспільної шкоди, яка завдається чи може бути завдана такими діяннями; по-друге, значно відрізняється від сум штрафів, які застосовуються за

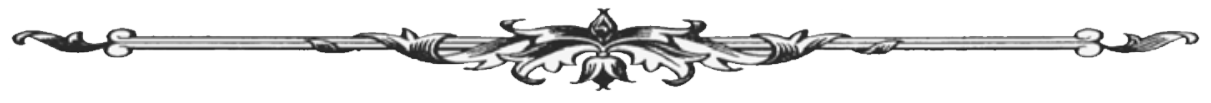


порушення правил і норм на авіаційному транспорті, хоча рівень безпеки експлуатації та загрози від його порушення на морському транспорті є не меншим.

Ключові слова: адміністративна відповідальність на морському транспорті, правопорушення наморськомутранспорті, видиадміністративних правопорушень на морському транспорті.

In the article on the basis of analysis of scientific looks a concept and features of administrative responsibility are considered as to the means of fight against offences on a marine transport. The concept of administrative responsibility is investigational, on the basis of what authorial determination of concept of administrative responsibility is given for offence on a marine transport as to the variety of legal responsibility, specific form of the negative reacting from the side of the state in the person of her competent organs on the feasance of offences on a marine transport, according to that persons that accomplished these offences must bear administrative penalties in the forms and order set by a law.

It is analysed, that administrative responsibility for offence on a marine transport is set by the head of a 10 Code of Ukraine about administrative crimes the "Administrative crimes on a transport, in industry of travelling economy and connection". The superficial analysis of syllables of these offences gives an opportunity to assert about absence of their clear system. For the removal of this blank, it is suggested to systematize offence on a marine transport on such groups: offences that trench upon safety of carrying passengers and loads a marine transport; offences that trench upon normal activity of marine transport and his infrastructure; violation of rules of behavior of passengers of marine ships.

On the basis of analysis of current legislation and opinions of scientists drawn conclusion, that today a problem is a question in relation to efficiency of approvals for the feasance of offences on a marine transport. In most cases for their feasance the insignificant sums of fines are used - from one to ten untaxable minimums of acuestss of citizens, that, firstly, is not correlated with the degree of public harm, that is inflicted, moreover can be inflicted by such acts; secondly, considerably differs from the sums of fines, that are used for violation of rules and norms on an aviation transport, although strength of exploitation and threat security from his violation on a marine transport is not less.

Key words: administrative responsibility on a marine transport, offence on a marine transport, types of administrative crimes on a marine transport.

Вступ. Адміністративні правопорушення на морському транспорті є доволі поширеними видами адміністративних правопорушень, і пов'язано це, з одного боку, із вагомим місцем морського транспорту в національній мережі переміщення товарно-матеріальних цінностей (більше 40\% сировини, продукції, транспортних засобів і засобів виробництва імпортується в Україну й експортується з України морським транспортом), з іншого - 3 низьким рівнем відповідної превентивної діяльності.

Так, за офіційними даними щороку за вчинення правопорушень на морському транспорті складається близько 500 протоколів, видається близько 100 приписів та уповноваженими особами виноситься близько 400 постанов про притягнення до адміністративної відповідальності за вчинення правопорушень на морському транспорті [1]. Однак слід зазначити, що значна частина правопорушень на морському транспорті $\epsilon$ невиявленою у зв’язку із складностями в їх нормативному визначені та механізмі застосування заходів адміністративної відповідальності за їх вчинення, що потребує законодавчої деталізації складів таких правопорушень, проблемними є також питання щодо особливостей адміністративної відповідальності за вчинення правопорушень на морському транспорті.

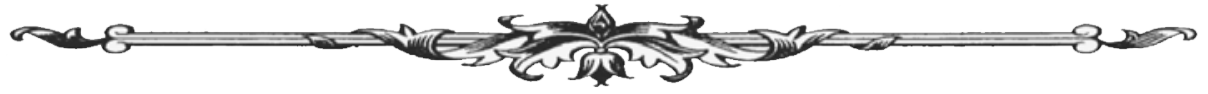


Необхідно зазначити, що питання адміністративної відповідальності протягом тривалого часу були предметом значної уваги науковців. Відповідній тематиці присвятили роботи такі вчені, як В.Б. Авер'янов, О.Ф. Андрійко, Д.М. Бахрах, Ю.П. Битяк, В.М. Бесчастний, Р.А. Калюжний, Д.П. Калаянов, М.В. Коваль, В.К. Колпаков, А.О. Селіванов, Х.П. Ярмакі та ін. Проте поняття й особливості адміністративної відповідальності як засобу боротьби 3 правопорушеннями на морському транспорті у працях зазначених вчених не розглядалися.

Постановка завдання. Метою статті є дослідження поняття й особливостей адміністративної відповідальності як засобу боротьби з правопорушеннями на морському транспорті.

Результати дослідження. Нині основним нормативно-правовим актом, який регулює питання охорони суспільного ладу, власності, соціально-економічних, політичних та особистих прав і свобод громадян, а також прав і законних інтересів підприємств, установ і організацій, встановленого порядку управління, державного і громадського порядку, зміцнення законності, запобігання правопорушенням, виховання громадян у дусі точного і неухильного додержання Конституції і законів України, поваги до прав, честі і гідності інших громадян, до правил співжиття, сумлінного виконання своїх обов'язків, відповідальності перед суспільством, $є$ Кодекс України про адміністративні правопорушення від 07 грудня 1984 p. (далі - КУПАП) [2].

Слід зауважити, що на теренах нашої держави у ії науковому просторі питання встановлення адміністративної відповідальності за правопорушення на морському транспорті не були належно проаналізовані. Розробки вчених присвячені переважно дослідженню інституту адміністративної відповідальності загалом та окремих сфер суспільства, але меншою мірою торкаються адміністративної відповідальності на морському транспорті. Серед наукового доробку, присвяченого дослідженню адміністративної відповідальності за правопорушення на морському транспорті, слід виокремити деякі наукові роботи. «Адміністративна відповідальність за порушення правил перевезення пасажирів і вантажів морським транспортом» (автор - А.Ю. Пеховський) [3] у межах якої проаналізовано підстави та зміст адміністративної відповідальності за порушення правил перевезення пасажирів і вантажів морським транспортом, розкрито суб'єктивні й об’єктивні ознаки адміністративних деліктів у цій сфері; виділено особливості провадження у справах про адміністративні проступки щодо порушення правил перевезення пасажирів і вантажів морським транспортом. «Адміністративно-правові засади нагляду та контролю за безпекою судноплавства в Україні» (автор - А.П. Калініченко [4]) в межах якої визначено юридичний склад адміністративних проступків, пов'язаних із порушенням безпеки судноплавства; проаналізовано особливості адміністративної відповідальності за порушення безпеки судноплавства та розроблено окремі пропозиції та рекомендації щодо ії удосконалення.

Перш ніж визначити поняття адміністративної відповідальності на морському транспорті, необхідно розглянути поняття адміністративної відповідальності взагалі. Слід зазначити, що чинне законодавство не дає визначення поняття адміністративної відповідальності, окрім того, по-різному воно тлумачиться і в теорії адміністративного права. $€$ два різновиди визначення адміністративної відповідальності: через об'єктивний і суб'єктивний підходи. Перший зумовлений відповідною негативною реакцією держави на протиправні прояви через встановлення окремих заборон, відповідних правил тощо й адекватних санкцій (заходів покарання) щодо порушників цих правил. В основі суб' єктивного підходу лежить особистий обов'язок порушника відповісти перед компетентними державними органами (ix службовими особами) за своє протиправне діяння і понести покарання згідно зі встановленим законом порядком.

Поєднавши ці два підходи, С. Гончарук визначає адміністративну відповідальність як різновид правової відповідальності, що є специфічною формою негативного реагування держави в особі іï компетентних органів на відповідну категорію протиправних проявів (передусім адміністративних проступків). Особи, котрі скоїли ці правопорушення, повинні дати відповідь перед уповноважним державним органом за свої неправомірні дії та зазнати за це адміністративних стягнень в установлених законом формах і порядку [5, с. 19].

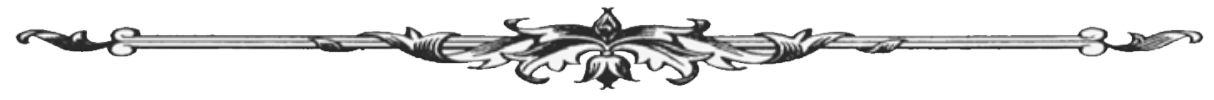


На думку Д. Овсянко, адміністративна відповідальність - це застосування державними органами, посадовими особами та представниками влади встановлених державою заходів адміністративного покарання до громадян, а у певних випадках - i до організацій за порушення законності та державної дисципліни [6, с. 129].

А.Т. Комзюк визначає адміністративну відповідальність як застосування до осіб, які вчинили адміністративні проступки, адміністративних стягнень, що тягнуть для цих осіб обтяжливі наслідки майнового, морального, особистого чи іншого характеру і накладаються уповноваженими на те органами чи посадовими особами на підставах і у порядку, встановлених нормами адміністративного права [7, с. 7].

Обгрунтованої позиції в цьому аспекті дотримується В.К. Колпаков [8, с. 7], який під адміністративною відповідальністю розуміє примусове, з додержанням встановленої процедури, застосування уповноваженим суб' єктом передбачених законодавством за вчинення адміністративного проступку заходів впливу. 3 цього випливає, що реальна адміністративна відповідальність настає за наявності нормативних, фактичних і документальних підстав.

Аналіз думок із цього приводу дає змогу дійти висновку, що поняття адміністративної відповідальності науковцями розглядається як один із інститутів адміністративного права, як форма забезпечення одного із заходів примусу (стягнення), як різновид юридичної (правової) відповідальності, як ефективний засіб запобігання вчинення правопорушень і забезпечення правопорядку, як певний стан суспільних відносин, який виникає внаслідок порушення законодавства [9, с. 81].

Адміністративну відповідальність за правопорушення на морському транспорті встановлено главою 10 КУпАП «Адміністративні правопорушення на транспорті, в галузі шляхового господарства і зв'язку». У сфері, що розглядаємо, адміністративну відповідальність передбачено за: порушення правил по охороні порядку і безпеки руху на морському транспорті (ст. 114); порушення правил користування засобами морського транспорту (ст. 115); порушення правил реєстрації торговельних суден (ст. 116 ${ }^{3}$; порушення правил пожежної безпеки на залізничному, морському, річковому і повітряному транспорті (ст. 120); допуск до керування транспортними засобами або суднами водіїв чи судноводіїв, які перебувають у стані алкогольного, наркотичного чи іншого сп'яніння або під впливом лікарських препаратів, що знижують їх увагу та швидкість реакції, або осіб, які не мають права керування транспортним засобом (ст. 129); керування транспортними засобами або суднами особами, котрі перебувають у стані алкогольного, наркотичного чи іншого сп'яніння або під впливом лікарських препаратів, що знижують їх увагу та швидкість реакції (ст. 130); порушення правил перевезення небезпечних речовин і предметів на транспорті (ст. 133); провезення ручної поклажі понад установлені норми і неоплаченого багажу (ст. 134); порушення правил, спрямованих на забезпечення схоронності вантажів на залізничному, морському, річковому й автомобільному транспорті (ст. 136); невиконання законних вимог посадових осіб органів морського і річкового транспорту (ст. $188^{15}$ ).

Поверховий аналіз складів цих правопорушень дає можливість стверджувати про відсутність чіткої їх системи. Погоджуємося з А.Ю. Пеховським, який пропонує систематизувати правопорушення на морському транспорті на такі групи: правопорушення, що посягають на безпеку перевезення пасажирів і вантажів морським транспортом; правопорушення, які посягають на нормальну діяльність морського транспорту та його інфраструктуру; порушення правил поведінки пасажирів морських суден [10, с. 211; 11, с. 148].

По-перше, доцільно було б об'єднати в межах окремої статті правопорушення, пов'язані з завданням матеріальної шкоди об’єктам морського транспорту, це, наприклад, ст. 114 пошкодження споруд і пристроїв сигналізації та зв’ язку; ч. 1, 2 ст. 136 - порушення правил, спрямованих на забезпечення схоронності вантажів на морському транспорті. По-друге, об'єднати в одній статті види адміністративних правопорушень, пов'язаних із порушенням пасажирами правил поведінки на морському транспорті у процесі його експлуатації, до яких варто включити: ст. 115 - порушення правил користування засобами морського транспорту; ст. 120 - порушення правил пожежної безпеки на залізничному, морському, річковому і пові-

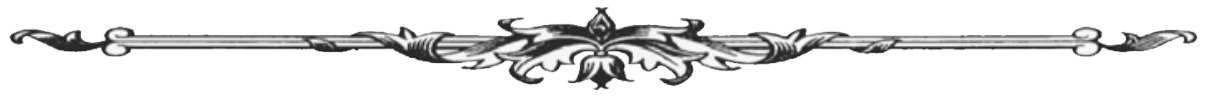


тряному транспорті. Правила поведінки на морському транспорті мають бути чітко прописані й доведені до відома пасажирів, котрі перебувають на морському судні.

Сьогодні у науці адміністративного права відсутній єдиний погляд на поняття та зміст підстав адміністративної відповідальності. Вчені зійшлися на тому, що єдиною підставою адміністративної відповідальності $є$ вчинення адміністративного правопорушення, тобто протиправної, винної (умисної або необережної) дії чи бездіяльності, яка посягає на громадський порядок, власність, права і свободи громадян, на встановлений порядок управління і за яку законом передбачено адміністративну відповідальність. Під адміністративним правопорушенням на морському транспорті слід розуміти суспільно небезпечне, протиправне, винне діяння, що посягає на встановлені порядок і безпеку руху на морському транспорті, правила користування засобами морського транспорту, правила випуску судна у плавання або допуску до керування судном осіб, котрі не мають відповідного документа, порушення правил реєстрації торговельних суден, перевезення пасажирів і вантажів морським транспортом, за яку законом передбачено адміністративну відповідальність. Адміністративним правопорушенням на морському транспорті притаманні такі ознаки: протиправність, винність, караність і суспільна шкідливість [12, с. 42].

Згідно з розділом 1 Наказу Міністерства інфраструктури України «Про затвердження Порядку оформлення матеріалів про адміністративні правопорушення на морському та річковому транспорті» від 18 квітня 2013 р. [13] за вчинення адміністративного правопорушення органи морського і річкового транспорту можуть застосовувати такі адміністративні стягнення: попередження; штраф; позбавлення права керування судном, маломірним судном, всіма видами плавучих засобів. До неповнолітніх осіб віком від шістнадцяти до вісімнадцяти років, які вчинили адміністративне правопорушення, застосовуються заходи впливу, передбачені ст. $24^{1}$ КУпАП.

Аналіз гл. 10 КУпАП дозволяє зробити висновок, що за вчинення адміністративних правопорушень на морському транспорті можуть бути застосовані такі види адміністративних стягнень - попередження, штраф, позбавлення права керування судном, маломірним судном, всіма видами плавучих засобів, громадські роботи або адміністративний арешт. Слід зазначити, що відповідно до розділу 1 Наказу Міністерства інфраструктури України «Про затвердження Порядку оформлення матеріалів про адміністративні правопорушення на морському та річковому транспорті» за вчинення адміністративного правопорушення органи морського і річкового транспорту можуть застосовувати такі адміністративні стягнення: попередження; штраф; позбавлення права керування судном, маломірним судном, всіма видами плавучих засобів, однак ст. 130 КУпАП передбачено застосування за керування річковими або маломірними суднами судноводіями в стані алкогольного, наркотичного чи іншого сп'яніння або під впливом лікарських препаратів, що знижують іх увагу та швидкість реакції, а так само передача керування судном особі, яка перебуває в стані такого сп'яніння чи під впливом таких лікарських препаратів, а також відмова осіб, котрі керують річковими або маломірними суднами від проходження відповідно до встановленого порядку огляду на стан алкогольного, наркотичного чи іншого сп'яніння або щодо вживання лікарських препаратів, що знижують увагу та швидкість реакції, накладення штрафу в розмірі ста п’ятдесяти неоподатковуваних мінімумів доходів громадян або позбавлення права керування всіма видами плавучих засобів на строк від одного до трьох років, або громадські роботи на строк від сорока до шістдесяти годин, або адміністративний арешт на строк від десяти до п’ятнадцяти діб. Тому, на нашу думку, необхідно узгодити ці нормативно-правові акти шляхом внесення відповідних доповнень до Наказу Міністерства інфраструктури України «Про затвердження Порядку оформлення матеріалів про адміністративні правопорушення на морському та річковому транспорті».

Необхідно зазначити, що Кабінет Міністрів України схвалив проект Закону України «Про внесення змін до Кодексу України про адміністративні правопорушення щодо підвищення розмірів стягнень за порушення законодавства з безпеки на морському та річковому транспорті» [14]. Проект Закону України «Про внесення змін до Кодексу України про

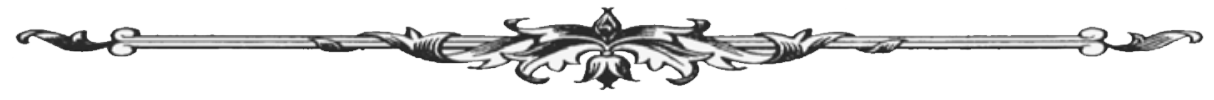


адміністративні правопорушення» розроблено Державною інспекцією України з безпеки на морському та річковому транспорті з метою підвищення розміру штрафних санкцій за правопорушення у сфері морського та річкового транспорту, що, на думку фахівців, дасть змогу якісніше здійснювати заходи щодо контролю (нагляду) у зазначеній сфері, сприятиме здійсненню дієвого впливу, спрямованого на дотримання вимог законодавства у сфері забезпечення безпеки судноплавства на морському та річковому транспорті, а також спонукатиме фізичних і юридичних осіб утримуватися від правопорушень. Крім того, збільшення розмірів штрафів дозволить збільшити надходження до Державного бюджету України.

За керування транспортними засобами або суднами особами у стані алкогольного, наркотичного чи іншого сп'яніння або під впливом лікарських препаратів, що знижують їхню увагу та швидкість реакції, передбачено штраф від 3400 грн до 5100 грн. Також Проектом Закону передбачено збільшення штрафів за керування незареєстрованими суднами; суднами, що не пройшли технічного огляду, або не несуть бортових номерів і позначень, або мають несправності тощо, з 17-85 грн до 510-850 грн; за керування судном особою, яка не має права керування цим судном, або передача керування таким судном особі, яка не має права керування, із 51-85 грн до 340-850 грн. Однак, на нашу думку, з метою боротьби 3 правопорушеннями на морському транспорті розміри стягнень, які передбачено проектом Закону України «Про внесення змін до Кодексу України про адміністративні правопорушення», повинні бути збільшені вдвічі, а то і в тричі.

Висновки. Проведене дослідження дозволило зробити висновок, що адміністративна відповідальність за правопорушення на морському транспорті - це різновид правової відповідальності, специфічна форма негативного реагування з боку держави в особі іiі компетентних органів на вчинення правопорушень на морському транспорті, згідно з якою особи, що скоїли ці правопорушення, повинні понести адміністративні стягнення у встановлених законом формах і порядку.

Сьогодні проблемним є питання щодо ефективності санкцій за вчинення правопорушень на морському транспорті. Так, здебільшого за їх вчинення застосовуються незначні суми штрафів - від одного до десяти неоподаткованих мінімумів доходів громадян, що, по-перше, не співвідноситься зі ступенем суспільної шкоди, яка завдається чи може бути завдана такими діяннями; по-друге, значно відрізняється від сум штрафів, які застосовуються за порушення правил і норм на авіаційному транспорті, хоча рівень безпеки експлуатації та загрози від його порушення на морському транспорті $є$ не меншим. Так, пошкодження внутрішнього обладнання суден карається штрафом від одного до трьох неоподаткованих мінімумів доходів громадян, тоді як пошкодження повітряних суден і їхнього устаткування тягне за собою накладення штрафу від п’ятдесяти до чотирьохсот неоподаткованих мінімумів доходів громадян. Тому, на нашу думку, за вчинення зазначених діянь штрафи повинні бути збільшені, як це зроблено на авіаційному й автомобільному транспорті.

Таким чином, на нашу думку, необхідно внести зміни до ст. 114, 115, 116 $, 120,129$, $130,133,135,136,188^{15}$ КУПАП шляхом підвищення суми штрафних санкцій за вчинення правопорушень на морському транспорті. Тому що розмір штрафу, який передбачено санкцією статті за вчинення правопорушень на морському транспорті, не відповідає сучасному стану, адже штраф у сумі 51 грн не досягає мети адміністративного стягнення, як це закріплено у ст. 23 КУпАП, - виховання особи, яка вчинила адміністративне правопорушення, в дусі додержання законів України, поваги до правил співжиття, а також запобігання вчиненню нових правопорушень як самим правопорушником, так і іншими особами. Прийняття зазначених змін буде сприяти зменшенню та припиненню правопорушень на морському транспорті, усуненню їх негативних наслідків, забезпеченню правомірної поведінки суб'єктів і дозволить посилити адміністративну відповідальність.

Одним із видів правопорушень на морському транспорті є правопорушення, передбачене ст. 134 КУпАП «Провезення ручної поклажі понад установлені норми і неоплаченого багажу», тобто встановлено відповідальність за провезення ручної поклажі понад установлені норми на залізничному, морському і річковому транспорті. Ручна поклажа -

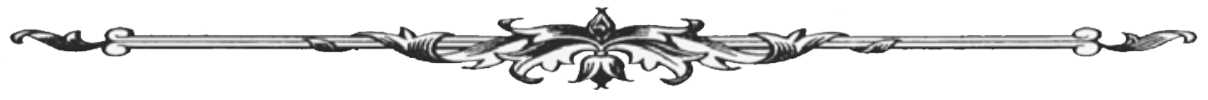


це предмети або речі, які перевозяться разом із пасажирами. Слід зазначити, що відомчими нормативними актами встановлено певні норми щодо ваги та габаритів такої поклажі для провезення на залізничному, повітряному й автомобільному транспорті. Однак слід констатувати той факт, що, на відміну від залізничного, повітряного й автомобільного транспорту, де встановлено вимоги до ручної поклажі, щодо морського транспорту нині немає жодного нормативно-правового акта, який би встановлював вимоги до провезення ручної поклажі на морському транспорті, тим більш немає статистичних даних щодо кількості притягнутих осіб до відповідальності за порушення правил перевезення ручної поклажі на морському транспорті. За порушення ч. 1 ст. 134 КУпАП передбачено накладення штрафу від 0,5 до одного неоподатковуваного мінімуму доходів громадян (від 8 грн 50 коп до 17 грн), тому, на нашу думку необхідно ст. 134 виключити із КУпАП у зв'язку з їі неефективністю.

Окрім того, з метою уніфікації термінології пропонуємо у назві ст. 116 КУПАП «Порушення правил по охороні порядку і безпеки руху на річковому транспорті і маломірних суднах» термін «руху» замінити на термін «експлуатації». Під експлуатацією засобів морського, річкового транспорту та маломірних суден пропонуємо розуміти будь-яке використання особою, яка має право на вчинення певних дій (керування, зупинення, стоянка та ін.), засобів морського, річкового транспорту та маломірних суден.

\section{Список використаних джерел:}

1. Укрморрічінспекція підбила підсумки контрольно-наглядової діяльності у 2014 році - заборонено експлуатацію 14 маломірних суден та 66 баз стоянок, складено 543 протоколи про адміністративні правопорушення. URL: http://mtu.gov.ua/news/19320.html.

2. Кодекс України про адміністративні правопорушення від 07 грудня 1984 р. / Верховна Рада України. Відомості Верховної Ради Украӥнської РСР. 1984. Додаток до № 51. Ст. 1122.

3. Пеховський А.Ю. Адміністративна відповідальність за порушення правил перевезення пасажирів і вантажів морським транспортом : дис. ... канд. юрид. наук : 12.00.07. Запоріжжя, 2017. 198 с.

4. Калініченко А.П. Адміністративно-правові засади нагляду та контролю за безпекою судноплавства в Україні : дис. ... канд. юрид. наук : 12.00.07. Київ, 2011. 198 с.

5. Гончарук С.Т Адміністративна відповідальність за законодавством України. Київ : Генеза, 1995. 78 с.

6. Овсянко Д.М. Административное право : учебное пособие / под ред. Г.А. Туманова. Москва : Юристь, 1997. 448 с.

7. Адміністративна відповідальність в Україні : навчальний посібник / Комзюк А.Т., Гуменюк В.А., Джагупов Г.В. та ін. ; за заг. ред. А.Т. Комзюка. Харків : Вид-во Ун-ту внутр. справ, 2007. 80 с.

8. Колпаков В.К. Адміністративна відповідальність. Сутність поняття і підстави. Вісник прокуратури. 2003. № 6. С. 75-79.

9. Алфьоров С.М., Ващенко С.В., Долгополова М.М., Купін А.П. Адміністративне право. Загальна частина : навчальний посібник. Київ : Центр навчальної літератури, 2011. 216 с.

10. Пеховський А.Ю. Особливості застосування заходів адміністративної відповідальності за порушення правил перевезення пасажирів і вантажів морським транспортом. Порівняльно-аналітичне право: електронне наукове фахове видання. 2015. № 5. С. 209-215.

11. Пеховський А.Ю. Особливості адміністративно-правової кваліфікації порушень правил перевезення пасажирів і вантажів морським транспортом. Науковий вісник Херсонського державного університету. 2016. Вип. 6. Т. 2. С. 146-149.

12. Кукшинова О.О., Біла В.Г. Підстави адміністративної відповідальності за правопорушення на морському транспорті. Науковий вісник Ужгородського національного університету. Серія: Право. 2017. Вип. 44 (2). С. 40-43. URL: http://nbuv.gov.ua/UJRN/ nvuzhpr_2017_44(2)__11.

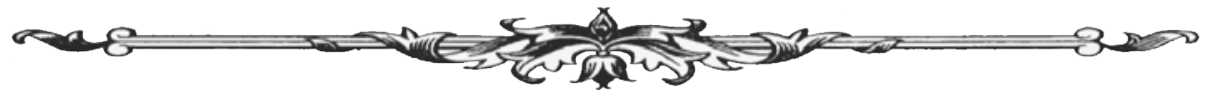


13.Про затвердження Порядку оформлення матеріалів про адміністративні правопорушення на морському та річковому транспорті : Наказ Міністерства інфраструктури України від 18 квітня 2013 р. (станом на 01 листопада 2019 р.). URL: http://zakon2.rada.gov. ua/laws/show/z0744-13.

14.Про внесення змін до Кодексу України про адміністративні правопорушення щодо підвищення розмірів стягнень за порушення законодавства з безпеки на морському та річковому транспорті : Проект Закону України. URL: http://w1.c1.rada.gov.ua/pls/ zweb2/webproc2 5_1_J? date1=\&date2=\&id=\&name_ zp=\%EA $\%$ EE $\%$ E4\%E5\%EA $\%$ F $1 \% F 3 \&$ num $=\&$ num _s $=2 \&$ out type $=\&$ page $=165 \& z p \_c n t=20$.

БЕРНАДІН В. А., ад’юнкт кафедри публічного управління та адміністрування

(Національна академія внутрішніх справ)

УДК 341.45:342.2:336.222

DOI https://doi.org/10.32842/2078-3736-2019-6-2-2

\section{ЗАРУБІЖНИЙ ДОСВІД ПРОТИДІЇ ПРАВОПОРУШЕННЯМ У СФЕРІ ОБІГУ ПІДАКЦИЗНИХ ТОВАРІВ}

У статті проаналізовано зарубіжний досвід правової регламентації суспільних відносин щодо протидії правопорушенням у сфері обігу підакцизних товарів. Запропоновано організаційно-правові заходи 3 метою підвищення ефективності протидії таким правопорушенням. Рекомендовано внести зміни до чинного законодавства для впровадження організаційно-правові моделі фінансової поліції чи служби фінансових розслідувань.

Визначено організаційно-правові моделі подальшого створення фінансової поліції чи служби фінансових розслідувань, аналоги яких можливо зустріти в інших державах, запропоновано розглянути питання створення на базі підрозділів Державної фіскальної служби України, Державної фінансової інспекції України, підрозділів Національної поліції та Служби безпеки України спеціального центрального органу виконавчої влади, який матиме повноваження запобігання та протидії правопорушення у фінансовій сфері й економіці, в т. ч. щодо протидії правопорушенням у сфері обігу підакцизних товарів, і підпорядковуватиметься Міністерству фінансів України.

Визначено, що створення і функціонування фінансової поліції чи служби фінансових розслідувань дозволить: створити єдиний орган, уповноважений на протидію правопорушенням у сфері обігу підакцизних товарів, який буде концентрувати необхідні повноваження. Зазначене усуне дублювання наявних повноважень Національної поліції України, Служби безпеки України та Державної фіскальної служби України щодо протидії правопорушенням у сфері обігу підакцизних товарів. Крім, того, дозволить організувати дієву взаємодію з іншими правоохоронними органами у процесі обміну інформацією, а також забезпечити достатній рівень матеріально-технічного, інформаційно-комунікаційного, соціального забезпечення. Створення такого органу вимагає кропіткої кадрової роботи, що допоможе набрати досвідчених, професійних працівників

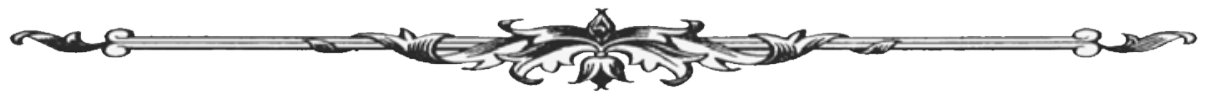

